\title{
Aile Eğitim Programının Annelerin Ebeveynlik Davranışlarına ve Çocuklarında Gözlenen Davranış Problemlerine Etkisi
}

DOI: 10.26466/opus.704706

\author{
Ali Çekiç* - Çiğdem Altuntaş ** \\ * Dr.Öğr.Üyesi, Gaziantep Üniversitesi, Eğitim Fakültesi, Eğitim Bilimleri, Gaziantep/Türkiye \\ E-Posta: alicekic79@gmail.com ORCID: 0000-0002-7893-268X \\ ** Psikolojik Danışman ve Rehber Öğretmen, MEB, Gaziantep/Türkiye \\ E-Posta: cigdem_altuntas_@hotmail.com_ORCID: 0000-0002-7097-0593
}

\begin{abstract}
Öz
Bu araştırma Akılı Duygusal Davranış̧̧ Terapiye (ADDT) dayalı Aile Eğitim Programı'nın annelerin ebeveynlik davranışları ile çocuklarında algıladıkları davranış problemleri üzerindeki etkisini incelemektir. Çalışmaya çocukları ilkokula devam eden 28 anne katılmıştır. Katılımcılardan 14 anne deney grubunu oluştururken 14 anne kontrol grubunu oluşturmaktadır. Uygulama öncesinde deney ve kontrol gruplarına Alabama Ebeveyn Davranışlar Ölçeği ve Conners' Anababa Derecelendirme Ölçeği uygulanmıştır. Öntest ölçümlerinin ardından deney grubuna 7 oturumdan oluşan Akılcı Duygusal Aile Eğitim Programı uygulanırken, kontrol grubu ile herhangi bir çalışma yapılmamıştır. Deney ve kontrol gruplarına uygulamalarm bitiminden 1 hafta sonra sontest ölçümleri gerçekleştirilmiştir. Elde edilen verilerin analizinde $2 x 2$ yönlü varyans analizi tekniği kullanılmıştır. Yapılan analizler sonucunda aile eğitim programına katılan annelerin çocuklarında bu eğitim programına katılmayan annelerin çocuklarına göre annelerin çocukları için algıladıkları davranış problemlerinde önemli düzeyde azalma olduğu annelerin işlem öncesine göre kendi ebeveynlik rollerine ilişkin olumlu tutum ve davranışların arttığı olumsuz tutum ve davranışların ise azaldığı görülmektedir. Elde edilen sonuçlar ilgili alanyazın ile karşılaştırılarak tartışılmış ve öneriler sunulmuştur.
\end{abstract}

Anahtar Kelimeler: Annelik, Ebeveynlik Becerileri, Çocuk Davranış Problemleri, Akılcı Duygusal Ĕ̆itim. 


\title{
The Effect Of Family Education Programme On Mothers' Parenting Behaviors And Behaviour Problems Of Their Children
}

\begin{abstract}
This study aims to examine effect of parent education programme based on REBT on maternal parenting behaviors and on behavioral problems perceived by mothers. 28 mothers attended to study who have children in primary school. 14 of participants are the experimental group while 14 of them are control group. Alabama parental behavior scale and Conner's parent rating scale were applied to experimental and control groups before application. After pretesting, 7-session rational emotive parent education programme were applied to experimental group. No session was apllied to control group. posttest evaluations were applied one week later of the end of sessions. The gathered data were analysed with $2 x 2$ anova. In conclusion of analysis, compared to mothers who didnt attend the parent education programme, the behaviors perceived as problem by mothers who attended parent education programme significantly decreased. While positive attitude and behaviors of the attended mothers increased, negative attitude and behaviors decreased.
\end{abstract}

Keywords: Motherhood, Pareningt skills, Behavioral problems in Children, Rational Emotive Education 


\section{Giriş}

Bir psikolojik danışman olarak okulda çalışmak anne-çocuk ilişkilerini gözlemleme açısından oldukça önemli bir firsat sunmaktadır. Çocuklarının yaşadıkları ya da annelerin çocuklarında problem olarak algıladıkları akademik başarısızlık, kardeşler ve akranlar arasında yaşanan problemler ve saldırganlık gibi sorunların çözümü için okulun rehberlik servisine başvuran pek çok annenin ebeveynlikle ilgili çoğu konuda kafasının karışık olduğu söylenebilir. Rehberlik servisine başvuran bazı anneler doğru tutumun ne olduğunu bilmekte fakat bu tutumları davranışa dönüştürmekte güçlük çekmetedir. Bazı anneler bu konuda eşleri ile işbirliği yapamakatan şikeyet ederken, bazıları ise babaanne, anneanne ve dede gibi geniş aile üyelerinin sürece müdahale etmelerinden şikâyet etmektedirler.

Türk Dil Kurumuna [TDK] (2018) göre aile, evlilik ve kan bağına dayanan, karı, koca, çocuklar, kardeşler arasındaki ilişkilerin oluşturduğu toplum içindeki en küçük birliktir. Aile bu yönüyle bireyin yaşamındaki ilk ve en önemli yıllarını geçirdiği, kişilik ve davranışlar üzerinde önemli etkilere sahip en küçük sosyal gruptur. Bu tanımdan da anlaşıldığı üzere sosyalleşme süreci ilk olarak çocuğun dünyaya geldiği aile ortamında başlar. Annesi, babası, varsa kardeşleri, akrabalıyla deneyimlediği etkileşimler sonucunda oluşur. Söz konusu etkileşim zamanla farklı sosyal çevrelerin etkisiyle genişleyerek devam eder (Can, 2011).

Dünya da olduğu gibi (McKenry ve Price, 2005) Türkiye'de de zaman içinde aile kurumunda aile içi ilişkilerde, rol ve statülerde ciddi değişiklikler yaşanmıştır. Geniş aileden çekirdek aileye geçişler yaşanmıştır. Ailedeki kişi sayısında azalmalar görülürken boşanma oranlarında artışlar görülmüş ailenin devamlılığı sekteye uğramış, kadınların işgücüne katılım düzeyi artmıştır (Kağıtçıaşı, 2006). Yaşanan bu değişimler bazı sorunları da beraberinde getirmiştir. Ebeveynlerin aile ve çocuk eğitimi konusunda destek alabilecekleri büyükanne, büyükbaba ve komşular gibi informal kanallara ulaşımını zorlaştırmıştır (Hareven,1982; akt: Staton ve ark. 1991). Geleneksel destek kanalları değişen ve ortadan kalkan ailelerkendilerine destek olup fayda sağlayacak eğitim programlarına gereksinim duyabilmektedir (Kılıç, 2010).

Çağdaşlaşma, evrenselleşme ve kitle iletişim araçlarının kullanımı ile duygusal yakınlık, sosyallik, bağlılık gibi kavramlar değişmiştir (Poole, 
2005). Ebeveynler aile üyelerinin psikolojik gereksinimlerini giderebilmeyi kendilerine görev edinmişlerdir (Kağıtçıbaşı, 2006; Pais, 2006). Anne babalar; kendilerini geliştirme, ebeveynlik becerileri ve rollerine ilişkin pozitif duygular edinme, çocuklarını tanıma, çocuklarının gelişimini sağlama hakkında desteğe gereksinim duyarlar (Tezel Şahin ve Cevher Kalburan, 2009). Sosyal değerlerin hızla değişmesi neticesinde anne babalar yeni değerler karşısında çocuklarına karşı nasıl davranacakları ve onları nasıl eğitecekleri konularında belirsizlik yaşamaktadır. Bu belirsizliklerin ortadan kaldırılması için kişilerin gerek ebeveyn olmadan önce gerekse de sonrasında gereksinim hissettikleri zaman, çocukların bakımı ve eğitimi konularında bilgilendirilmeleri gerekmektedir (Tezel Şahin ve Özbey, 2007).

Günümüzde pek çok anne baba, çocuklarına yönelik nasıl bir tutum içinde olmaları gerektiği konusunda yeterli bilgi ve tecrübeye sahip olmadıkları için sorumlulukların yeriine getirmede yetersiz kalabilmektedir. $\mathrm{Bu}$ durum anne babalara ihtiyaç duydukları desteği sağlayacak aile eğitim programlarına dair önemli bir gereksinim oluşturmaktadır (Çağdaş, 2009).

Aile çocukların gelecek yaşantısını önemli ölçüde etkilediğinden, ebeveynlerin çocuk eğitimi, gelişimi ve yetiştirilmesi hakkında eğitim yaşantıları geçirmeleri, çocukların daha iyi yetiştirilmesinde önemli rol oynamaktadır (Kaya, 2002). Ebeveynlere verilecek akılcı olmayan düşünceleri değiştirmeye yönelik bir eğitim çocuklarda akılcı olmayan düşünme biçimlerini davranışsal ve duygusal sorunları azaltması söz konusudur. Yapılan çalışmalar da ADDT'ye dayalı uygulamaların ebeveynlerin akılcı olmayan düşüncelerinin (Stimac, 1985), kızgınlık, kendini değersiz görme (Joyce, 1995), ebeveynlik stres düzeylerinin azaltılmasında (Gavita ve ark. 2011) olumlu etkisi olduğu görülmektedir.

Anne babaların, çocuk eğitimi ve gelişimi konusunda bilgi sahibi olmamaları ya da yetersiz bilgileri, yanlış ebeveyn tutumlarına sebep olabilmektedir (Tezel Şahin ve Özbey, 2007). Çocuğun akranlarıyla kıyaslanması, ebeveynin şiddet içerikli davranması, çocuğa devamlı ceza uygulanması ve çocuğun girişimlerinin desteklenmemesi çocuklarda saldırganca davranışların oluşmasına neden olmaktadır (Dizman, 2003). Yanlış ebeveyn tutumu ve düzensiz aile yapıları, sağlısız büyümenin ve tuttarsız ve dengesiz davranışların temel nedenlerinden olabilir. Ebeveynin bazen çocuğun kendi gelişimini engelleyecek düzeyde çocuğa her şeyi vermesi bazen de çocuğa ge- 
rekli desteği sağlayamayacak düzeyde çok az şey vermesi problem davranışlarının oluşmasına yol açmaktadır (Geçtan, 2008).

Çocuklarda görülen davranış problemleri hem Türkiye'de hem de bazı ülkelerde liderler, eğitimciler ve aileler için kaygı kaynağı olmaktadır. Davranış problemleri çocukların psikolojik, fiziksel ve duyusal verilerinin işlemleme sırasında meydan gelen dengesizlikler sonucu içsel sıkıntıların davranışlarla kendini göstermesidir (Alisinanoğlu, Kesicioğlu, 2010). Gelişim sürecinde çocuk ve ergenler problemli davranışlar gösterebilirler. Problem davranışlar uygun önlemler alınmadığında, çocuğun kişiliği ile karakterize olup bireyin yetişkinlik dönemlerinde yasal olarak ceza gerektirecek davranışlara, akademik yetersizliğe, sosyal çevre ile uyum sorunu ve sorunun büyümesine ve süreklileşmesine yol açabilmektedir (Rocha-Decker,2004). Davranım bozukluğu tedavisi konusunda maliyetli bir rahatsızlıktır. Pek çok tedavi yöntemleri denenmiştir. Tedavilerden bir kısmı sonuç verirken pek azı etkili olmuştur. Ebeveyn eğitimleri en sağlıklı ve etkili tedavi yöntemlerindendir diyebiliriz (Krol, Morton, ve De-Bruyn, 2004).

Davranış sorunu gösteren çocuklar ile yapılan çalışmalarda problemi gösteren çocukların annelerinin, iletişim becerilerinin zayıf olduğu ve çocuklarına yaklaşırken sağlıksız ebeveyn tutumu sergiledikleri görülmüştür. Çocukların sosyal beceri edinmesinde, kendilerini kontrol etmelerini sağlamada, çocuğun rol model edinirken içselleştirmesinde anne ve çocuk arasındaki bağın kalitesinin etkili olduğu düşünülmektedir (Turan, 2004). Çocuklar anne ve babalarını örnek alarak onlarla özdeşleşirler, anne ve babalarının tutum ve davranışlarını model alarak özümserler (Aksoy, 2005).

Aile, insanın yaşamının sonuna kadar etkisini sürdürür. Aile çocuğun psikolojik gelişimini yön verip sosyal yaşantısına rehberlik eder. (Yavuzer, 1996). Sorgulayıcı, denetleyici, etiketleyici, katı ve aile üyelerine karşı otoriter olan davranış biçimleri aile içindeki çatışmaların çoğalmasına yol açmaktadır (Baltaş ve Baltaş, 2002). Anne babanın akılcı veya akılcı olmayan davranışları, çocuğun sağlıklı veya sağlıksız bir yetişkin olmasında etkilidir (Ellis, Moosley ve Wolfe, 1966).

Yapılan araştırmalar anne babaların akılcı olmayan inançları ile çocuk yetiştirme tarzları (Hauck, 1967), aile ortamı (Stimac, 1985), annebaba-çocuk arasındaki karşılıklı etkileşimin rolü (Kandır, 2000) aileden algılanan sosyal destek (Öksüz ve ark. 2011), çocuğun aşırı kaygılı ebeveynlerle yaşaması (Beautrais, Fergusson ve Shannon, 1982; Starko, 1991), çocuklarda gözlenen 
problem davranışlar (Bağcl, 2013) arasında ilişki olduğunu ortaya koymuştur. Ayrıca anne babaların fonksiyonel olmayan ilişki inançları arttıkça ergen çocuklarına yönelik çatışma çözme becerileri azalmakta, anne baba ve ergen arasındaki ilişki zarar görmektedir (Hamamc1, 2007).

Bütün bu araştırmalar dikkate alındığında annelerin hem kendilerine, hem ilişki yaşadıkları kişilere hem de ebeveynlik rollerine ilişkin akılcı olmayan inançlarının bazı olumsuz sonuçları olduğu görülmektedir. Akılcı düşünme becerileri zayıf olan annelerin kendilerine ilişkin duygu ve davranışları olumsuz olabilirken aynı zamanda çocuk yetiştirmeye yönelik olan ebeveynlik inançları ve bu inançların şekillendirdiği davranışları da olumsuz özellikler içerebilmektedir. Üstelik gelişim erken dönemleri çocuklar için pek çok kritik dönem içermekte, bu dönemlerde karşılaşılan olumsuz ebeveyn davranışları ergenlik ve yetişkinlik yıllarını da etkileyebilmektedir.

Erikson'un psikososyal gelişim kuramında söz ettiği ilkokul yıllarını kapsayan altı on bir yaşları arasında çevresinden destek gören çocuğun öz saygısı artmakta ve çocuk daha çok çalışmaya yönelmekteyken desteklenmeyen çocuk ise yaptıklarının değersiz olduğuna inanmaktadır. Yetersizlik duygusu yaşayan çocukta çevresiyle sağlıklı ilişkiler kuramama ve uyum güçlüğü gibi sorunlar görülebilmektedir (Gökmen, 2004)

Ebeveynlerin aşırı otoriter ve yargllayıcı tutum sergilemesi bireyde paranoid bir kişiliğe (güvensiz, kuşkucu) yol açabilmektedir. Ödünleme savunma mekanizmasında kaynaklı davranışları sorunları da yaşanabilmektedir. Ebeveynlerin kendi eksiklerinden ya da edindikleri aşağılık duygusu sebebiyle başka bir alanda abartılı bir ödünleme çabasına girmesi ve çocuklarından da bunları beklemesi çocuğun özsaygını geliştirmesini engellemektedir, insanlara karşı güvensizliğin oluşmasına yol açmaktadır ve kendini yalnız hissetmesine neden olmaktadır (Geçtan, 2013). Baskıcı, kıstlayıcı bir ailede yetişen çocuklarda, genellikle asi ve başkaldıran davranışlara aşağılık duygusu eşlik edebilir. Bu ailelerde büyüyen çocukların otokontrolü düşüktür ve bu çocuklar daha çok başkalarının denetimlerine ihtiyaç duyarlar. (Yavuzer, 2013).

Anne ve babaların çocuğa karşı tutumları, tavırları, davranışları hem çocuğun gelişimini etkileyerek gelecekteki davranışlarına yön verir hem de sosyal çevrenin normlarına ve beklentilerine paralel, çevresiyle uyumlu bir insan olarak yetişip yetişmediğini belirler. (Demirkaynak, Aktaş ve Hasipek, 2006). 
Çocuğuna tutarlı bir disiplin uygulayan aşırı koruyucu davranmadan şefkat ve sevgi ile yaklaşan çocuğun psikolojik ve fiziksel gereksinimlerini karşılayan girişimini destekleyen ebeveyn çocuğun sağlıklı kişilik gelişimi açısından en yararlı tutumu benimsemektedir. (Çağdaş, 2012;Özdemir vd. 2012). Bu ortamda yetişen çocukların özgüveni-özsaygısı gelişmiş, düşüncelerini özgürce ifade edebilen, gerekli riskleri alabilen, gelişime değişime açık, diğer insanlara saygılı ve orijinal fikirler üretme kapasitesine sahip bireyler olduklarını söyleyebiliriz (Kulaksızoğlu, 2008).

Çocuğun güzel ve yaralı bir şeyler başarabilme düşüncesi edinmesi, onun istekli ve başarılı olma duygusunu geliştirip bu yönde harekete geçmesini sağlar. Olumsuz düşünceler ve yetersiz olduğu duygusu ise değersizlik duygusunu geliştirmesine ve bunu destekleyecek davranışlara dönüşmesine neden olur (Erikson, 1968).

Aile yapılarında, rollerinde ve fonksiyonlarında meydana gelen değişimler literatürde yer alan çalışmaların temel ilgi alanını oluşturmakta ve ailenin karşılaştığı sorunların nasıl ortadan kaldırılacağı ile ilgilenmektedir (Çağan,2011). Aile eğitim programları sonunda ebeveynlerin çocuk eğitimi ve gelişimi konusunda kendilerini daha bilgili, donanımlı ve yeterli hissettikleri, çocuklarının davranış problemlerine gerekli müdahalede bulunup kalıcı çözümler üretebildikleri görülmektedir (Bekman,2000). Çocuklarının kişilik gelişimini sosyal ve psikolojik yönden olumlu destekleyen akademik başarısına katkı sağlayan ebeveyn modeli gözlenmiştir (Temel, 2010).

$\mathrm{Bu}$ araştırmanın genel amacı ADDT' ye dayalı Aile Eğitim Programı'nın annelerin ebeveynlik davranışları üzerindeki etkisini incelemektir. Araştırma kapsamında annelere uygulanan aile eğitim programının odak noktası annelerin ebeveyn rollerine ilişkin sahip oldukları akılcı olmayan inançların daha esnek ve akılcı inançlara dönüştürmektir. Böylelikle annelerin ebeveyn rollerinde gösterdikleri ve olumsuz ebeveyn davranışları olarak nitelendirilebilecek çocuğa yönelik şiddet, tutarsız disiplin uygulamaları, çocuk yetiştirirken gösterilen yetersiz destek gibi istenmeyen ebeveyn davranışlarının azaltılması amaçlanmaktadır.

Çalışmanın aynı zamanda ADDT'ye dayalı Aile Eğitim Programı'na dahil olan annelerin çocuklarında algıladıkları davranış problemleri üzerindeki etkisini incelemektir. Ebeveyn tutumları çocuklarda davranış sorunlarına yol açabilmektedir. Ebeveynlerin demokratik, otoriter, mükemmeliyetçi, ihmalci, koruyucu veya reddedici tutumlarının çocuklar üzerinde çok farklı 
etkileri olabilmektedir (Arı, 2005). Ebeveyn tutumlarının davranış sorunlarına etkisini incelediği çalışmada baskıcı ve disiplinli ebeveyn tutumu ile çocuklardaki davranış problemleri arasında pozitif yönde anlamlı ilişki olduğu ortaya çıkmıştır (Engin, 2015). Bu noktada annelerin ebeveynlik rollerine ilişkin sahip oldukları akılcı olmayan inançların azaltılması, daha akılcı inançların öğretilmesi çocuklarında algıladıkları davranış problemlerinin azaltılmasında olumlu katkı sağlayabileceği düşünülmektedir.

\section{Yöntem}

Araştırma, ADDT'ye dayalı bir aile eğitim programının etkililiğinin sınanmasını amaçlayan yarı deneysel çalışmadır. Araştırmada öntest, sontest ve deney-kontrol gruplu 2x2'lik split-pot, faktöryel (karışık) desen kullanılmıştır (Büyüköztürk, 2010).Araştırmada katılımcıların demografik özellikleri hakkında bilgi toplamak amacıyla Kişisel Bilgi Formu, ebeveynlerin çocuklarını yetiştirirken nasıl davrandıklarını ve uyguladıkları tutumlarını ölçmek amacıyla Alabama Ebeveyn Davranışları Ölçeği [AEDÖ], annelerin çocuklarında algıladıkları davranış problemlerini ölçmek amacıyla Conners' Anababa Derecelendirme Ölçeği [CADÖ] kullanılmıştır.Araştırmanın yapılacağı eğitim kurumunda okul yönetiminin izni ve eğitim-öğretim personelinin yardımı ile CADÖ ve AEDÖ ilkokul ikinci, üçüncü ve dördüncü sınıf öğrencileri aracilığıyla annelere ulaştırılmıştır. Araştırmanın nedeni ve ölçeğin içeriği hakkında bilgi sunan bir metin de beraberinde gönderilmiştir. Annelerin doldurduğu veri araçları öğrencilerin aracılığıyla sınıf öğretmenleri tarafından toplanmıştır. Araştrımacıya teslim edilmiştir.

\section{Veri Toplama Araçları}

Alabama Ebeveyn Davranışları Ölçeği: Frick (1991) tarafından geliştirilen Alabama Ebeveyn Davranışları Ölçeği'nin Türkçe'ye uyarlanma çalışması Çekiç, Türk, Buğa ve Hamamcı (2018) tarafından yapılmıştır. Alabama Ebeveyn Davranışları Ölçeği'nin orijinali ilköğretim kademesinde çocuğu olan anne-babalar ile geliştirilmiştir (Shelton, Frick, ve Wootton, 1996). Ölçek 6-18 yaş arası çocuklara ve 6-18 yaş yaş aralığında çocuk sahibi olan ebeveynlere yönelik iki farklı formu bulunmaktadır (Çekiç ve ark., 2018). Ölçek ebeveynlerin çocuklarını yetiştirirken nasıl davrandıklarını ve uyguladıkları tutumlarını ölçmektedir. Ölçek 35+7 maddeden oluşmakta ve ebeveyn davranışla- 
rını 5 farklı alanda incelemektedir. (Frick, Christian ve Wootton,1999). Bunlar;

- $\quad$ Çocukla İlgilenme(ÇI)

- Olumlu Ebeveynlik (OE)

- Zayıf Ebeveyn Takibi (ZET)

- Tutarsiz Disiplin (TD)

- Dayakla Cezalandırma (DC) alt boyutlarıdır.

Aynı zamanda AEDÖ' de DC alt boyutuna karşı ebeveynler tarafından bir önyargı oluşmasını engellemek için 7 madde daha ölçek uygulamalarında yer almaktadır. Bu maddeler bir alt boyut olarak puanlanmamaktadır (Shelton, Frick ve Woolton, 1996). Ölçekte (Frick, 1991):

- Olumlu ebeveyn davranışlarını; Çİ ve OE alt boyutları ile

- Olumsuz ebeveyn davranışlarını; ZET, TD ve DC alt boyutlar ile ölçülmektedir.

Bu araştırma kapsamında AEDÖ'nün toplam puana ilişkin Cronbach Alfa iç tutarlılık katsayısı .70'tir. İç tutarlılık katsayısı 0 ile +1 arasında değer alır ve 1'e ne kadar yakınsa güvenirliğin o oranda arttığı anlamını taşır (Can, 2014). AEDÖ' nün hem Türkçe' ye uyarlama çalışmasından elde edilen sonuçlar incelendiğinde hem de bu araştırma kapsamında elde edilen iç tutarlılık katsayısı göz önünde bulundurulduğunda, Ülkemizde yaşayan ebeveynlerin çocuk yetiştirme konusunda olumlu ve olumsuz davranışlarını değerlendirebilen geçerli ve güvenilir bir ölçme aracı olduğu söylenebilir.

Conners' Anababa Derecelendirme Ölçeği: Conners' Anababa Derecelendirme Ölçeği çocuklarda görülen davranış problemlerini ölçmektedir. Ölçeğin Türkçe uyarlaması Şener ve arkadaşları tarafından yapılmıştır (Şener ve ark. 1998). Orijinal ölçekte (evrensel) ve Türkçe uyarlama çalışmasında (yerel) çocuklarındaki "davranım sorunu", "ataklık/hiperaktivite”, "öğrenme sorunu", "kaygı" ve "psikosomatik" olarak adlandırılan davranışları ölçmektedir. Ölçeğin Cronbach Alfa ile değerlendirilen iç tutarlığı .90 olarak hesaplanmıştır. "Öğrenme sorunu" alt ölçeği haricinde diğer alt ölçeklerin iç tutarlılığının yeterli düzeyde olduğu bildirilmiştir (Dereboy ve ark. 2006).

Araştırmacılar CADÖ için başlıca 3 kullanım alanı olduğunu ifade etmişlerdir. Bunlar; çocuklarda rastlanılan problemli davranışları belirlemek için bir test aracı, konulan tanıları desteklemek için yardımcı araç ve uygulanı- 
lan tedavilerin sonuçlarının değerlendirilmesi için izlem aracı olmasıdır (Giannaris ve ark. 2001).

Toplam 48 maddeden oluşan Conners' Anababa derecelendirme ölçeği beş alt ölçekten oluşmaktadır (Dereboy, Senol, Sener, 2006). Bu alt ölçekler şunlardır:

- Davranim Sorunları

- Hiperaktivite

- Öğrenme sorunları

- Kaygr

- Psikosomatik

CADÖ 4'lü likert tipi bir veri toplama aracıdır. 4 yanıt seçeneği vardır. Hiç Yok (hiçbir zaman doğru değil, çok ender), 0 puan; biraz (bazen doğru), 1 puan; oldukça fazla (sık sık, oldukça doğru), 2 puan; çok (çok sık doğru), 3 puan. Ölçek puanlanırken her bir madde 0-3 arasında değişen değer alır. Yüksek puan, çocuğun CADÖ'de belirtilen problem davranışa o kadar çok sahip olduğunu gösterir. Conners' Anababa Derecelendirme Ölçeğinden elde edilecek en düşük puan 0; en yüksek puan ise 144'tür.

\section{Deney ve Kontrol Gruplarmm Belirlenmesi}

Çalışmaya dâhil olacak anneleri belirlemek için Gaziantep'te çocukları devlet ilkokuluna devam eden 351 anneye uygulanan CADÖ'nün toplam puanları dikkate alınmıştır. Uygulanan ölçekler sonunda grubun $(n=351)$ elde ettiği puanın aritmetik ortalamasının $(=72,70)$ bir tam standart sapma üzerinde $(S s=13,79)$ puan alan 55 anne ile görüşmeler yapılmıştır. Yapılan görüşmeler neticesinde detayları verilen eğitim programına katılmak için istekli, herhangi bir patalojik problem olmayan ya da halihazırda ilaç veya psikoterapi gibi psikolojik bir tedavi almayan, karar verilen ortak gün ve saatte eğitim programına katılabilen 14 anne deney grubunda yer almıştır. CADÖ'nün aritmetik ortalamasının bir tam standart sapma üzerinde puan alan fakat eğitime dâhil olamayan sontest ölçümlerine katılmayı kabul eden ve dışarıda bırakılma kriterlerini taşımayan 14 anne de kontrol grubuna dâhil edilmiştir. 


\section{Verilerin Analizi}

Araştırmada elde edilen verilerin analizinde kullanılacak istatistiksel yöntemleri belirlemek amaciyla deney ve kontrol gruplarındaki annelerin AEDÖ ve CADÖ testinden aldıkları öntest puanlarının parametrik testlerin temel varsayımlarını karşılayıp karşılamadıkları incelenmiştir. Verilerin normal dağılım göstermesi parametrik testlerin temel varsayımlarından biridir. Bu varsayımın karşılanıp karşılanmadığını test etmek amacıyla deney ve kontrol gruplarının Conners' Anababa Derecelendirme Ölçeği toplam puan ve alt boyutlarda elde edilen Shapiro-Wilks değerleri ve çarpıklık (skewness) ve basıklık (kurtosis) katsayıları incelenmiştir.

Tablo 1. Deney ve kontrol gruplarının Conners' Anababa Değerlendirme Ölçeğinden elde edilen ön-test puanlarna ilişkin normallik testleri

\begin{tabular}{llllllll}
\hline Ölçek & Grup & $\overline{\mathbf{X}}$ & Ss & Medyan & Shapiro Wilks & Çarpıklık & Basıklık \\
\hline Conners' & Deney & 94,21 & 8,77 & 90,5 &, 005 & 1,445 & 1,295 \\
\cline { 2 - 8 } & Kontrol & 95,43 & 7,32 & 94,5 &, 114 & 1,283 & 2,007 \\
\hline
\end{tabular}

Tablo 1 incelendiğinde deney grubunun ön-test puanına ilişkin Shapiro Wilks değeri .05'ten küçüktür ve çarpıklık ve basıklık katsayılarına bakıldığında çarpıklık ve basıklık katsayılarının -1 ile +1 aralığında olmadığı; deney grubunun normalden daha basık ve çarpık olduğu görülmektedir. Kontrol grubunun ön-testlerine ilişkin Shapiro Wilks değerine bakıldığında ise .05 'ten büyük olduğu fakat basıklık ve çarpıklık katsayılarının -1 ile +1 arlığında olmadığı, normalden daha basık ve çarpık olduğu görülmektedir.

Tablo 2. Deney ve kontrol gruplarnın Alabama Ölçeğinden elde edilen ön-test puanlartna ilişkin normallik testleri

\begin{tabular}{llllllll}
\hline Ölçek & Grup & $\overline{\mathbf{X}}$ & Ss & Medyan & $\begin{array}{l}\text { Shapiro } \\
\text { Wilks }\end{array}$ & Çarpıklık & Basıklık \\
\hline Alabama & Deney & 37,86 & 3,37 & 39 &, 139 &,- 573 &,- 768 \\
İGİ & Kontrol & 35,5 & 5,93 & 36,5 &, 040 & $-1,257$ & 1,147 \\
Alabama & Deney & 25,07 & 3,75 & 26,5 &, 174 & $-1,085$ & 1,217 \\
OE & Kontrol & 23,64 & 5,36 & 25 &, 097 & $-1,264$ & 2,058 \\
Alabama & Deney & 17,93 & 4,87 & 17 &, 735 &, 497 &, 081 \\
ZET & Kontrol & 20,71 & 5,54 & 20 &, 646 &,- 018 &,- 977 \\
Alabama & Deney & 16,57 & 2,28 & 16,5 &, 554 &, 074 &,- 074 \\
TD & Kontrol & 15 & 4,62 & 16,5 &, 030 & $-1,029$ &, 135 \\
Alabama & Deney & 7,14 & 1,23 & 7 &, 052 & $-1,177$ & 2,309 \\
DC & Kontrol & 6,29 & 1,54 & 7 &, 199 &,- 412 &, 329 \\
\hline
\end{tabular}

İLGİ: Çocukla İlgilenme, OE: Olumlu Ebeveynlik, ZET: Zayıf Ebeveyn Takibi, TD:Tutarsız Disiplin, DC: Dayakla Cezalandırma 
Tablo 2 incelendiğinde deney grubunun Alabama Ölçeğinin tüm alt boyutlarda elde ettikleri ön-test puanlarına ilişkin Shapiro Wilks değerleri .05 'ten büyüktür fakat $\mathrm{OE}$ ve Dayak alt boyutlarında basıklık ve çarpıklık değerleri -1 ile +1 arasında yer almamaktadır. Kontrol grubunun Alabama Ölçeği ilgilenme ve tutarsız alt boyutlarında elde ettikleri ön-test puanlarına ilişkin Shapiro Wilks değerleri .05'ten küçüktür dolayısıyla normal bir dağ1lım göstermediği söylenebilir. Yine sosyal bilimlerdeki deneysel ve yarı deneysel çalışmalarda çalışma gruplarından her birindeki denek sayısı 15 'ten az olması durumunda parametrik olmayan testlerin kullanılması önerilmektedir (Büyüköztürk, 2010). Bu nedenle deney ve kontrol gruplar1nın Conners' Anababa Derecelendirme Ölçeğinden elde ettikleri ön-test ve son-testlerden aldıkları puan ortalamalarına göre gruplar arasında anlamlı bir fark olup olmadığını incelemek için iki farklı grubun ortalamalarının karşılaştırılmasında kullanılan ilişkisiz (Bağımsız) örneklemler İçin t-testinin non-parametrik karşılığı olan Mann-Whitney U testi kullanılmıştır.

\section{Bulgular}

Araştırmadan elde edilen verilerin analizinde önce deney ve kontrol gruplarının her iki ölçme araçlarından elde ettikleri aritmektik ortalama ve standart sapma değerleri verilmiştir. Daha sonra deney ve kentrol grupları puan ortalamları arasında işlem öncesinde anlamlı bir fark olup olmadığı Mann Whitney U testi incelenmiş, grupların kendi içlerindeki değişimin anlamlı olup olmadığını incelemek için ise Wilcoxon İşaretli Sıralar testi kullanılmıştir.

Tablo 3'te görüldüğü gibi deney grubunda yer alan katılımciların Conners' Anababa Derecelendirme Ölçeği'nin ön-test ölçümünden aldıkları puanların ortalaması 94,21 (Ss: 8,77); son-test ölçümünden aldıkları puanların ortalaması 77,64 (Ss: 11,48) olarak belirlenmiştir. Kontrol grubunda yer alan katılımcıların Conners' Anababa Derecelendirme Ölçeği'nin ön-test ölçümünden aldıkları puanların ortalaması 95,43 (Ss: 7,32); son-test ölçümünden aldıkları kayg1 puanlarının ortalaması 90,64 (Ss: 16,25) olarak ölçülmüştür. 
Tablo 3. Deney ve kontrol gruplarnın Conners' ölçeğinden almış olduklan ön-test, sontest ölçümlerine ait aritmetik ortalama ve standart sapmalarn

\begin{tabular}{|c|c|c|c|c|c|c|}
\hline \multirow[t]{2}{*}{ Ölçek } & \multicolumn{3}{|c|}{ Ön-test } & \multicolumn{3}{|c|}{ Son-test } \\
\hline & $\mathrm{n}$ & $x$ & Ss & $\mathrm{n}$ & $x$ & Ss \\
\hline \multicolumn{7}{|l|}{ Conners' } \\
\hline Deney & 14 & 94,21 & 8,77 & 14 & 77,64 & 11,48 \\
\hline Kontrol & 14 & 95,43 & 7,32 & 14 & 90,64 & 16,25 \\
\hline \multicolumn{7}{|c|}{ Conners'-DS } \\
\hline Deney & 14 & 20,14 & 4,47 & 14 & 17,07 & 2,70 \\
\hline Kontrol & 14 & 21,71 & 5,11 & 14 & 23,14 & 6,44 \\
\hline \multicolumn{7}{|c|}{ Conners'-DEH } \\
\hline Deney & 14 & 10,71 & 2,09 & 14 & 8,71 & 2,23 \\
\hline Kontrol & 14 & 10,43 & 2,21 & 14 & 10,57 & 1,87 \\
\hline \multicolumn{7}{|c|}{ Conners'-ÖS } \\
\hline Deney & 14 & 11,57 & 3,13 & 14 & 10,07 & 2,23 \\
\hline Kontrol & 14 & 11,29 & 2,92 & 14 & 10,14 & 2,57 \\
\hline \multicolumn{7}{|c|}{ Conners'-Kayg1 } \\
\hline Deney & 14 & 19,57 & 3,32 & 14 & 14,93 & 3,32 \\
\hline Kontrol & 14 & 18,36 & 2,92 & 14 & 16,71 & 2,40 \\
\hline \multicolumn{7}{|c|}{ Conners'-PS } \\
\hline Deney & 14 & 8,21 & 2,55 & 14 & 7,14 & 2,41 \\
\hline Kontrol & 14 & 9,07 & 3,77 & 14 & 7,43 & 2,56 \\
\hline
\end{tabular}

DS:Davranım Sorunları, DEH : Dikkat Eksikliği Hiperaktivite, ÖS: Öğrenme Sorunları, Kayg: Kayg1 Sorunları, PS: Psikosomatik Sorunlar

Tablo 4. Deney ve kontrol gruplarnın Alabama Ölçeği'nden almış olduklan ön-test, sontest ölçümlerine ait aritmetik ortalama ve standart sapmalarn

\begin{tabular}{|c|c|c|c|c|c|c|}
\hline \multirow[t]{2}{*}{ Ölçek } & \multicolumn{3}{|c|}{ Ön-test } & \multicolumn{3}{|c|}{ Son-test } \\
\hline & $\mathbf{n}$ & $x$ & Ss & $\mathbf{n}$ & $x$ & Ss \\
\hline \multicolumn{7}{|c|}{ Alabama-İLGİ } \\
\hline Deney & 14 & 37,86 & 3,37 & 14 & 38,92 & 4,80 \\
\hline Kontrol & 14 & 35,50 & 5,93 & 14 & 33,29 & 7,10 \\
\hline \multicolumn{7}{|c|}{ Alabama-OE } \\
\hline Deney & 14 & 25,07 & 3,75 & 14 & 26,57 & 3,03 \\
\hline Kontrol & 14 & 23,64 & 5,36 & 14 & 22,43 & 6,62 \\
\hline \multicolumn{7}{|c|}{ Alabama-ZET } \\
\hline Deney & 14 & 17,93 & 4,87 & 14 & 15,64 & 5,21 \\
\hline Kontrol & 14 & 20,71 & 5,54 & 14 & 21,14 & 4,96 \\
\hline \multicolumn{7}{|c|}{ Alabama-TD } \\
\hline Deney & 14 & 16,57 & 2,28 & 14 & 15 & 3,31 \\
\hline Kontrol & 14 & 15 & 4,62 & 14 & 14,93 & 4,20 \\
\hline \multicolumn{7}{|c|}{ Alabama-DC } \\
\hline Deney & 14 & 7,14 & 1,23 & 14 & 5,71 & 1,98 \\
\hline Kontrol & 14 & 6,29 & 1,54 & 14 & 6,43 & 2,24 \\
\hline
\end{tabular}

Alabama Ebeveyn Davranışları Ölçeği'nin İlgilenme alt boyutuna bakıldığında deney grubunda yer alan katılımcıların son-test ölçümünden aldıkları puanların ortalaması $(38,92)$ ön-test ölçümünden aldıkları puanların 
ortalamasına $(37,86)$ göre yükselirken kontrol grubunda yer alan katılımc1ların İlgilenme alt boyutunun son-test ölçümünden aldıkları puanların ortalaması $(33,29)$ ön-test ölçümünden aldıkları puanların ortalamasına $(35,5)$ göre düşüş göstermiştir.

Alabama Ebeveyn Davranışları Ölçeği'nin Olumlu Ebeveynlik alt boyutuna bakıldığında deney grubunda yer alan katılımcılarınson-test ölçümünden aldıkları puanların ortalaması $(26,57)$ ön test ölçümünden aldıkları puanların ortalamasına $(25,07)$ göre yükselirken kontrol grubunda yer alan katılımcıların Olumlu Ebeveynlik alt boyutunun son-test ölçümünden aldıkları puanların ortalaması $(22,43)$ ön-test ölçümünden aldıkları puanların ortalamasina $(23,64)$ göre düşüş göstermiştir.

Alabama Ebeveyn Davranışları Ölçeği'nin Zayıf Ebeveynlik alt boyutuna bakıldığında deney grubunda yer alan katılımciların son-test ölçümünden aldıkları puanların ortalaması $(15,64)$ ön test ölçümünden aldıkları puanların ortalamasına $(17,93)$ göre düşerken kontrol grubunda yer alan kat1lımcların Zayıf Ebeveynlik alt boyutunun son-test ölçümünden aldıkları puanların ortalamasına $(21,14)$ ön test ölçümünden aldıkları puanların ortalamasına (20,71) göre yükselmiştir.

Alabama Ebeveyn Davranışları Ölçeği'nin Tutarsız Disiplin alt boyutuna bakıldığında deney grubunda yer alan katılımcıların son-test ölçümünden aldıkları puanların ortalaması (15) ön test ölçümünden aldıkları puanların ortalaması $(16,57)$ göre düşüş gösterirken kontrol grubunda yer alan kat1lımcıların Tutarsız Disiplin alt boyutunun son-test ölçümünden aldıkları puanların ortalaması $(14,93)$ ön test ölçümünden aldıkları puanların ortalamasına (15) göre yükselmiştir.

Alabama Ebeveyn Davranışları Ölçeği 'nin Dayak alt boyutuna bakıld1ğında deney grubunda yer alan katılımcların son-test ölçümünden aldıkları puanların ortalaması $(5,71)$ ön test ölçümünden aldıkları puanların ortalamasına $(7,14)$ göre düşüş göstermiştir. Kontrol grubunda yer alan katılımclların Dayak alt boyutunun son-test ölçümünden aldıkları puanların ortalaması $(6,43)$ ön test ölçümünden aldıkları puanların ortalamasına $(6,29)$ göre düşüş göstermiştir. 
Tablo 5. Deney ve kontrol gruplarnın Conners' Anababa Ölçeğinin ön-test ve son-test ölçümünden elde edilen puanlarn ortalamalarna ilişkin Mann-Whitney $U$ testi sonuçlarn

\begin{tabular}{|c|c|c|c|c|c|c|}
\hline Conners' & Grup & $\mathrm{n}$ & Sira Ortalaması & Sira Toplamı & $\mathbf{U}$ & $\mathrm{p}$ \\
\hline \multirow[t]{2}{*}{ Ön-test } & Deney & 14 & 13,21 & 185 & 80 & 0,406 \\
\hline & Kontrol & 14 & 15,79 & 221 & & \\
\hline \multirow[t]{2}{*}{ Son-test } & Deney & 14 & 11 & 154 & 49 & 0,024 \\
\hline & Kontrol & 14 & 18 & 252 & & \\
\hline \multicolumn{7}{|c|}{ Conners'-DS } \\
\hline \multirow[t]{2}{*}{ Ön-test } & Deney & 14 & 13,18 & 184,5 & 79,5 & 0,393 \\
\hline & Kontrol & 14 & 15,82 & 221,5 & & \\
\hline \multirow[t]{2}{*}{ Son-test } & Deney & 14 & 10,54 & 147,5 & 42,5 & 0,010 \\
\hline & Kontrol & 14 & 18,46 & 258,5 & & \\
\hline \multicolumn{7}{|c|}{ Conners'-DEH } \\
\hline \multirow[t]{2}{*}{ Ön-test } & Deney & 14 & 14,89 & 208,5 & 92,5 & 0,798 \\
\hline & Kontrol & 14 & 14,11 & 197,5 & & \\
\hline \multirow[t]{2}{*}{ Son-test } & Deney & 14 & 11,29 & 158 & 53 & 0,037 \\
\hline & Kontrol & 14 & 17,71 & 248 & & \\
\hline \multicolumn{7}{|c|}{ Conners'-ÖS } \\
\hline \multirow[t]{2}{*}{ Ön-test } & Deney & 14 & 14,79 & 207 & 94 & 0,853 \\
\hline & Kontrol & 14 & 14,21 & 199 & & \\
\hline \multirow[t]{2}{*}{ Son-test } & Deney & 14 & 14,36 & 201 & 96 & 0,926 \\
\hline & Kontrol & 14 & 14,64 & 205 & & \\
\hline \multicolumn{7}{|c|}{ Conners'-Kaygı } \\
\hline \multirow[t]{2}{*}{ Ön-test } & Deney & 14 & 15,71 & 220 & 81 & 0,432 \\
\hline & Kontrol & 14 & 13,29 & 186 & & \\
\hline \multirow[t]{2}{*}{ Son-test } & Deney & 14 & 12,07 & 169 & 64 & 0,115 \\
\hline & Kontrol & 14 & 16,93 & 237 & & \\
\hline \multicolumn{7}{|c|}{ Conners'-PS } \\
\hline \multirow[t]{3}{*}{ Ön-test } & Deney & 14 & 13,79 & 193 & 88 & 0,642 \\
\hline & Kontrol & 14 & 15,21 & 213 & & \\
\hline & Deney & 14 & 14,14 & 198 & 93 & 0,814 \\
\hline Son-test & Kontrol & 14 & 14,86 & 208 & & \\
\hline
\end{tabular}

$\mathrm{p}<0,05$

Tablo 5 incelendiğinde deney ve kontrol gruplarının Conners' Anababa Derecelendirme Ölçeğinin toplam ön-test puan ortalamaları $\left[\mathrm{U}_{(28)}=80, \mathrm{p}>\right.$ 0,05] arasinda anlamlı bir fark bulunmazken toplam son-test puan ortalamaları $\left[\mathrm{U}_{(28)}=49, \mathrm{p}<0,05\right]$ arasında istatistiksel olarak anlamlı bir fark olduğu gözlenmektedir.

Deney ve kontrol gruplarının Conners' Anababa Derecelendirme Ölçeguinin $\mathrm{DB}$ alt boyutunun $\left[\mathrm{U}_{(28)}=79,5, \mathrm{p}>0,05\right], \mathrm{DE}$ alt boyutunun $\left[\mathrm{U}_{(28)}=92,5\right.$, $\mathrm{p}>0,05]$, ÖG alt boyutunun [ $\left.\mathrm{U}_{(28)}=94, \mathrm{p}>0,05\right]$, kayg1 alt boyutunun [ $\mathrm{U}_{(28)}=$ $81, \mathrm{p}>0,05]$ ve $P S$ alt boyutunun $\left[\mathrm{U}_{(28)}=88, \mathrm{p}>0,05\right]$ ön-test puan ortalamaları arasında istatistiksel olarak anlamlı bir fark olmadığı görülmektedir. 
Öte yandan deney ve kontrol gruplarının Conners' Anababa Derecelendirme Ölçeğinin DB alt boyutunun $\left[\mathrm{U}_{(28)}=42,5\right.$, $\left.\mathrm{p}<0,05\right]$ ve $\mathrm{DE}$ alt boyutunun $\left[\mathrm{U}_{(28)}=53, \mathrm{p}<0,05\right]$ son-test puan ortalamaları arasinda anlamlı bir fark görülürken; ÖG alt boyutunun [ $\left.\mathrm{U}_{(28)}=96, p>0,05\right]$, kayg1 alt boyutunun $\left[\mathrm{U}_{(28)}=64, \mathrm{p}>0,05\right]$ ve PS alt boyutunun $\left[\mathrm{U}_{(28)}=93, \mathrm{p}>0,05\right]$ son-test puan ortalamaları arasında istatistiksel olarak anlamlı bir fark olmadığ görülmektedir.

Tablo 6. Deney ve kontrol gruplarnın Alabama Ölçeğinin ön-test ve son-test ölçümünden elde edilen puanlarn ortalamalarna ilişkin Mann-Whitney $U$ testi sonuçlarn

\begin{tabular}{|c|c|c|c|c|c|c|}
\hline Alabama-İLGí & Grup & $n$ & Sira Ortalaması & Sira Toplamı & $\mathrm{U}$ & $p$ \\
\hline \multirow[t]{3}{*}{ Ön-test } & Deney & 14 & 16,04 & 224,5 & 76,5 & 0,318 \\
\hline & Kontrol & 14 & 12,96 & 181,5 & & \\
\hline & Deney & 14 & 17,86 & 250 & 51 & 0,030 \\
\hline Son-test & Kontrol & 14 & 11,14 & 156 & & \\
\hline \multicolumn{7}{|l|}{ Alabama-OE } \\
\hline \multirow[t]{2}{*}{ Ön-test } & Deney & 14 & 15,64 & 219 & 82 & 0,458 \\
\hline & Kontrol & 14 & 13,36 & 187 & & \\
\hline \multirow[t]{2}{*}{ Son-test } & Deney & 14 & 16,5 & 231 & 70 & 0,195 \\
\hline & Kontrol & 14 & 12,5 & 175 & & \\
\hline \multicolumn{7}{|l|}{ Alabama-ZET } \\
\hline \multirow[t]{2}{*}{ Ön-test } & Deney & 14 & 12,46 & 174,5 & 69,5 & 0,189 \\
\hline & Kontrol & 14 & 16,54 & 231,5 & & \\
\hline \multirow[t]{2}{*}{ Son-test } & Deney & 14 & 10,32 & 144,5 & 39,5 & 0,007 \\
\hline & Kontrol & 14 & 18,68 & 261,5 & & \\
\hline \multicolumn{7}{|l|}{ Alabama-TD } \\
\hline \multirow[t]{2}{*}{ Ön-test } & Deney & 14 & 15,18 & 212,5 & 88,5 & 0,660 \\
\hline & Kontrol & 14 & 13,82 & 193,5 & & \\
\hline \multirow[t]{2}{*}{ Son-test } & Deney & 14 & 14,46 & 202,5 & 97,5 & 0,982 \\
\hline & Kontrol & 14 & 14,54 & 203,5 & & \\
\hline \multicolumn{7}{|l|}{ Alabama-DC } \\
\hline \multirow[t]{2}{*}{ Ön-test } & Deney & 14 & 17 & 238 & 63 & 0,095 \\
\hline & Kontrol & 14 & 12 & 168 & & \\
\hline \multirow[t]{2}{*}{ Son-test } & Deney & 14 & 13,32 & 186,5 & & \\
\hline & Kontrol & 14 & 15,68 & 219,5 & 81,5 & 0,436 \\
\hline
\end{tabular}

$\mathrm{p}<0,05$

Tablo 6. incelendiğinde deney ve kontrol gruplarının Alabama Ölçeği'nin ön test sonuçlarında ilgilenme alt boyutunun $\left[\mathrm{U}_{(28)}=76,5, \mathrm{p}>0,05\right], \mathrm{OE}$ alt boyutunun $\left[\mathrm{U}_{(28)}=82, \mathrm{p}>0,05\right], \mathrm{ZE}$ alt boyutunun $\left[\mathrm{U}_{(28)}=69,5, \mathrm{p}>0,05\right]$, tutarsiz disiplin alt boyutunun $\left[\mathrm{U}_{(28)}=88,5, \mathrm{p}>0,05\right]$ ve dayak alt boyutunun $\left[\mathrm{U}_{(28)}=63, \mathrm{p}>0,05\right]$ ön-test puan ortalamaları arasinda istatistiksel olarak anlamlı bir fark olmadığı görülmektedir. 
Öte yandan deney ve kontrol gruplarının Alabama Ölçeği'nin son test sonuçlarında ilgilenme alt boyutunun $\left[\mathrm{U}_{(28)}=51, \mathrm{p}<0,05\right]$ ve $\mathrm{ZE}$ alt boyutunun $\left[\mathrm{U}_{(28)}=39,5, \mathrm{p}<0,05\right]$ son-test puan ortalamaları arasinda anlamlı bir fark olduğu görülürken; $\mathrm{OE}$ alt boyutunun $\left[\mathrm{U}_{(28)}=70, \mathrm{p}>0,05\right]$, tutarsız disiplin alt boyutunun $\left[\mathrm{U}_{(28)}=97,5, \mathrm{p}>0,05\right]$ ve dayak alt boyutunun $\left[\mathrm{U}_{(28)}=81,5, \mathrm{p}>0,05\right]$ son-test puan ortalamaları arasında istatistiksel olarak anlamlı bir fark olmadığı görülmektedir.

Tablo 7. Deney grubunun Conners' Anababa Derecelendirme Ölçeği'nin ön-test ve sontest ölçümünden elde ettikleri puan ortalamalarna ilişkin Wilcoxon İşaretli Stralar testi sonuçları

\begin{tabular}{llllll}
\hline Ölçek & $\begin{array}{l}\text { Karşılaştırılan } \\
\text { Puanlar }\end{array}$ & $\begin{array}{l}\text { Sıra } \\
\text { Ortalaması }\end{array}$ & $\begin{array}{l}\text { Sıra } \\
\text { Toplamı }\end{array}$ & $\mathbf{z}$ & $\mathbf{p}$ \\
\hline Conners' Toplam Puan & Ön-test & 7,64 & 84 & $-2,691$ & 0,007 \\
& Son-test & 3,5 & 7 & & \\
\hline Conners'-DS & Ön-test & 7 & 63 & $-1,891$ & 0,059 \\
& Son-test & 5 & 15 & & \\
\hline Conners'-DEH & Ön-test & 7,39 & 66,5 & $-2,170$ & 0,030 \\
& Son-test & 3,83 & 11,5 & & \\
\hline Conners'-ÖS & Ön-test & 8,10 & 81 & $-1,801$ & 0,072 \\
& Son-test & 6 & 24 & & \\
\hline Conners'-Kayg1 & Ön-test & 8,82 & 97 & $-2,798$ & 0,005 \\
& Son-test & 2,67 & 8 & & \\
\hline Conners'-PS & Ön-test & 5,63 & 45 & $-1,812$ & 0,070 \\
& Son-test & 5 & 10 & & \\
\hline
\end{tabular}

$\mathrm{p}<0,05$

Tablo 7 incelendiğinde deney grubunun Conners' Anababa Derecelendirme Ölçeği'nin ön-test ve son-test ölçümlerinden elde ettikleri toplam puan ortalamaları $(\mathrm{z}=-2,691, \mathrm{p}<0,05), \mathrm{DE}$ alt boyutu puan ortalamaları $(\mathrm{z}=-$ 2,170, $p<0,05)$ ve Kaygı alt boyutu puan ortalamaları $(z=-2,798, p<0,05)$ arasında anlamlı bir fark olduğu gözlenirken; ön-test ve son-test ölçümlerinden elde ettikleri DB alt boyutunun $(\mathrm{z}=-1,891, \mathrm{p}>0,05)$ puan ortalamalarl, ÖG alt boyutunun puan ortalamaları $(z=-1,801, p>0,05)$ ve PS alt boyutunun $(z=-1,812, p>0,05)$ puan ortalamaları arasında anlamlı bir fark olmadığı görülmektedir. 
Tablo 8.Deney grubunun Alabama Ölçeği'nin ön-test-son-test ölçümünden elde ettikleri puan ortalamalarnna ilişkin Wilcoxon İşaretli Stralar testi sonuçlarn

\begin{tabular}{llllll}
\hline Ölçek & $\begin{array}{l}\text { Karşılaştrrilan } \\
\text { Puanlar }\end{array}$ & Sıra Ortalaması & $\begin{array}{l}\text { Sira } \\
\text { Toplamı }\end{array}$ & $\mathbf{z}$ & $\mathbf{p}$ \\
\hline Alabama-İLGI & Ön-test & 6,67 & 20 & $-1,165$ & 0,244 \\
& Son-test & 5,75 & 46 & & \\
\hline Alabama-OE & Ön-test & 4,63 & 18,5 & $-1,633$ & 0,103 \\
& Son-test & 7,44 & 59,5 & & \\
\hline Alabama-ZET & Ön-test & 8,7 & 87 & $-2,173$ & 0,030 \\
& Son-test & 4,5 & 18 & & \\
\hline Alabama-TD & Ön-test & 8,5 & 76,5 & $-1,518$ & 0,129 \\
& Son-test & 5,7 & 28,5 & & \\
\hline Alabama-DC & Ön-test & 6,44 & 58 & $-2,288$ & 0,022 \\
& Son-test & 4 & 8 & & \\
\hline
\end{tabular}

$\mathrm{p}<0,05$

Tablo 8 incelendiğinde deney grubunun Alabama Ölçeği'nin ön-test ve son-test ölçümlerinden elde ettikleri ZE alt boyutu puan ortalamaları ( $\mathrm{z}=$ 2,173, $\mathrm{p}<0,05)$ ve Dayak alt boyutu puan ortalamaları $(\mathrm{z}=-2,288, \mathrm{p}<0,05)$ arasında anlamlı bir fark olduğu gözlenirken; ön-test ve son-test ölçümlerinden elde ettikleri İlgilenme alt boyutunun $(z=-1,165, p>0,05)$ puan ortalamaları, OE alt boyutunun puan ortalamaları $(z=-1,633, p>0,05)$ ve Tutarsiz Disilin alt boyutunun $(\mathrm{z}=-1,518, \mathrm{p}>0,05)$ puan ortalamaları arasında anlamlı bir fark olmadığı görülmektedir.

Tablo 9. Kontrol grubunun Conners' Anababa Derecelendirme Ölçeği'nin ön-test-son-test ölçümünden elde ettikleri puan ortalamalarnna ilişkin Wilcoxon Işsaretli Stralar testi sonuçları

\begin{tabular}{llllll}
\hline Ölçek & $\begin{array}{l}\text { Karşılaştırılan } \\
\text { Puanlar }\end{array}$ & Sıra Ortalaması & $\begin{array}{l}\text { Sıra } \\
\text { Toplamı }\end{array}$ & $\mathbf{z}$ & $\mathbf{p}$ \\
\hline Conners' & Ön-test & 8,38 & 67 & $-0,912$ & 0,362 \\
Toplam Puan & Son-test & 6,33 & 38 & & 0,381 \\
\hline Conners'-DS & Ön-test & 5,5 & 33 & $-0,876$ & 0,811 \\
& Son-test & 8,29 & 58 & $-0,239$ & 0,207 \\
\hline Conners'-DEH & Ön-test & 7,20 & 36 & $-1,261$ & 0,282 \\
& Son-test & 6 & 42 & $-1,077$ & \\
\hline Conners'-ÖS & Ön-test & 9,06 & 72,5 & & 0,053 \\
& Son-test & 5,42 & 32,5 & $-1,931$ & \\
\hline Conners'-Kayg1 & Ön-test & 6,33 & 38 & 17 & \\
& Son-test & 4,25 & 73 & 18 & \\
\hline Conners'-PS & Ön-test & 8,11 & & & 0 \\
& Son-test & 4,5 & & & \\
\hline
\end{tabular}

$\mathrm{p}<0,05$ 
Tablo 9 incelendiğinde kontrol grubunun Conners' Anababa Derecelendirme Ölçeği'nin ön-test ve son-test ölçümlerinden elde ettikleri toplam puan ortalamaları $(\mathrm{z}=-0,912, \mathrm{p}>0,05)$, DB alt boyutunun $(\mathrm{z}=-0,876, \mathrm{p}>0,05)$ puan ortalamaları, DE alt boyutunun $(\mathrm{z}=-0,239, \mathrm{p}>0,05)$ puan ortalamaları, ÖG alt boyutunun $(\mathrm{z}=-1,261, \mathrm{p}>0,05)$ puan ortalamaları, Kayg1 alt boyutunun $(\mathrm{z}=-1,077, \mathrm{p}>0,05)$ puan ortalamaları ve PS alt boyutunun $(\mathrm{z}=-1,931$, $\mathrm{p}>0,05)$ puan ortalamaları arasında anlamlı bir fark olmadığı görülmektedir.

Tablo 10. Kontrol grubunun Alabama Ölçeği'nin ön-test-son-test ölçümünden elde ettikleri puan ortalamalarına ilişkin Wilcoxon İşaretli Stralar testi sonuçlarn

\begin{tabular}{llllll}
\hline Ölçek & $\begin{array}{l}\text { Karşılaştırılan } \\
\text { Puanlar }\end{array}$ & $\begin{array}{l}\text { Sıra } \\
\text { Ortalaması }\end{array}$ & $\begin{array}{l}\text { Sıra } \\
\text { Toplamı }\end{array}$ & $\mathbf{z}$ & $\mathbf{p}$ \\
& Ön-test & 8,75 & 70 & $-1,103$ & 0,270 \\
& Son-test & 5,83 & 35 & & \\
\hline Alabama-İLGI & Ön-test & 7,93 & 55,5 & $-0,701$ & 0,483 \\
& Son-test & 5,92 & 35,5 & & \\
\hline Alabama-OE & Ön-test & 6,14 & 43 & $-0,175$ & 0,861 \\
& Son-test & 8 & 48 & & \\
\hline Alabama-ZD & Ön-test & 6,83 & 41 & $-0,316$ & 0,752 \\
& Son-test & 7,14 & 50 & & \\
\hline Alabama-DC & Ön-test & 6,40 & 32 & $-0,090$ & 0,928 \\
& Son-test & 5,67 & 34 & & \\
\hline
\end{tabular}

$\mathrm{p}<0,05$

Tablo 10 incelendiğinde kontrol grubunun Alabama Ölçeği'nin ön-test ve son-test ölçümlerinden elde ettikleri İlgilenme alt boyutunun $(z=-1,103$, $p>0,05)$ puan ortalamaları, OE alt boyutunun $(z=-0,701, p>0,05)$ puan ortalamaları, $Z E$ alt boyutunun $(\mathrm{z}=-0,175, \mathrm{p}>0,05)$ puan ortalamaları, Tutarsı alt boyutunun $(z=-0,316, p>0,05)$ puan ortalamaları ve Dayak alt boyutunun $(\mathrm{z}=-0,090, \mathrm{p}>0,05)$ puan ortalamaları arasında anlamlı bir fark olmadığı görülmektedir.

\section{Sonuç ve Tartışma}

\section{Çocukların Davranış Problemlerine İlişkin Bulgularn Sonuç ve Tartışması}

Bu araştırmanın amacı ADDT'ye dayalı Aile Eğitim Programı'nın çocuklarda algılanan davranış problemleri üzerindeki etkilerini ortaya koymaktır. Elde edilen sonuçlar, aile eğitim programına katılan annelerin çocuklarında bu eğitim programına katılmayan annelerin çocuklarına göre annelerin çocukları için algıladıkları davranış problemlerinde azalma olduğu ortaya konulmuştur. Bu çalışmada uygulanan eğitim programı ağırlıklı olarak 
akılcı olmayan inançlar üzerine odaklanmıştır. Akılcı olmayan düşüncelerinin azaltılması ile annelerin çocuklarında algıladıkları davranış problemleri üzerinde de etkili olduğu şeklinde yorumlanabilir. Nitekim yapılan çalışmalarda annelerin sahip oldukları akılcı olmayan inançların çocuk yetiştirme tutumlarını etkilediği, akılcı düşünme becerileri ile birlikte anne babaların rahatladıkları, stres düzeylerinin azaldığı gözlenmekte ve daha etkili anne babalık becerileri sergilemektedirler (Grusec ve Davidov, 2007). Anne babalar akılcı disiplin yöntemleri ile çocukların gelişimlerini desteklemektedirler (Joyce, 1995).

Araştırma bulguları ADDT'ye dayalı Aile Eğitim programı annelerin genel olarak çocuklarında algıladıkları davranış problemleri düzeylerinin düşürülmesinde etkili olduğunu göstermektedir. CADÖ alt boyutları aç1sından değerlendirildiğinde, Davranım Sorunları ve DEHB alt boyutlarında annelerin çocuklarının davranışlarını deneysel işlem öncesine göre problem olarak algılamalarında anlamlı derecede azalma gözlenirken, Öğrenme Sorunları, Kaygılı Davranışlar ve Psikosomatik Davranışlar alt boyutları açısından annelerin çocuklarının davranışlarına ilişkin değerlendirmelerinde işlem öncesine göre anlamlı bir farklılık gözlenmemiştir. Davranım Sorunları ve DEHB alt boyutlarında yer alan maddelerin ifade ettiği bazı durumlar "Yerinde rahat duramaz, kıpır kıpırdır.", "Zarar vericidir (eşyalar)." Annelerin akılcı olmayan inançlarından kaynaklanan çocuğa yönelik gerçekçi olmayan beklentiler ve mükemmeliyetçi tutumlarından dolayı yanlış değerlendirilmiş olabileceği düşünülmektedir. Nitekim annelerin çocuklarının davranışlarına verdikleri duygusal ve davranışsal tepkiler büyük oranda düşüncelerinden etkilenmektedir (David, Oana ve Joyce, 2011) . Araştırmaya katılan annelerin hem düşüncelerinin değişmesi ile daha akılcı düşünme becerileri kazanmaları hem de çocuklarının normal gelişim dönemi özelliklerinden kaynaklanan davranışlarını öğrenmeleri sonucunda döneme özgü bazı davranışları yaramazlık ya da problem olarak görmek yerine, çocuğun doğasından kaynaklandığını sadece kendi çocuklarının değil, araştırmaya katılan diğer annelerin çocuklarının da benzer davranışlar sergilediklerini görmelerinin bu değişimde etkili olduğu düşünülmektedir.

Öğrenme Sorunları, Kaygılı Davranışlar ve Psikosomatik Davranışlar alt boyutları açısından annelerin değerlendirmelerinde herhangi bir değişiklik olmaması bu alt boyutlarda yer alan maddelerin daha klinik özellikler içermeleri "Yeme sorunları vardır(iştahı yoktur iki lokma arasında sofradan 
kalkar dolaşır)." veya yoruma imkan tanımayan daha somut davranış problemlerini "Yaşıtlarına göre konuşması farklıdır. (ör.bebeksi, kekeleme, anlaşılması güç)." ifade etmesinden kaynaklanabilir. Ayrıca eğitim ortamında müdahaleler gerektiren "Öğrenme Sorunları" , klinik müdahaleler gerektiren "Kaygilı Davranışlar ve Psikosomatik Davranışlar" alt boyutlarına ilişkin annelerin değerlendirmelerinin sadece annelerin akılcı olmayan inançlarına müdahale edildiği için değişmemiş olması da muhtemeldir. Çünkü çocukluk çağı davranış problemlerinin annelerin dışında etkileşimde olduğu bütün süreç ve elemanların başta diğer ebeveyn olan baba, diğer aile üyeleri, akranlar, iklim ve kültür gibi çevresel faktörler tarafından da etkilendiği bilinmektedir (Apter, 1982).

Ayrıca eğitim programının hem veri toplama aşamasında hem de uygulama sırasında babalar çalışmaya dâhil edilmemiştir. Çalışmanın hafta içi mesai saatlerinde yapılması, babaların bu saatlerde çalışıyor olması, uygulama yapılacak bölgede annelerin babalara göre çocuğun bakımı yetiştirilmesi konusunda daha fazla sorumluluk alması gibi zorunlu sebeplerden babalar çalışmaya alınmamıştır. Uygulamaya anneler tek ebeveyn olarak katılmışlardır. Ebeveynlerden sadece biri ile sınırlı kalması, çalışmanın etkililiğini sınırlandırmış olabilir. Uygulama esnasında öğrenilenlerin tam ve etkili bir şekilde diğer ebeveynle paylaşıldığı ve ebeveyn olarak davranışlarında olumlu değişikliğe yol açtı̆̆ aile ortamında uygulanmasında herhangi bir sıkıntı yaşanmadığı fakat etkinliğinin artması adına anneler çalışmaya diğer ebeveynin katılması gerektiği yönünde görüş bildirmişlerdir.

Araştırma kapsamında uygulanan ADDT'ye dayalı Aile Eğitim progra$\mathrm{m}$ ağırlıklı olarak annelerin beveynlik rollerine ilişkin düşüncelerini fark ettirmeye ve ve böylece ebeveylilğe ilişkin davranışlarını değiştirmeye yöneliktir. Programa katılan anneler oturum sonlarında araştırmacıya çocuklarının akademik başarılarını arttırmaya yönelik ve yemek yeme alışkanlıkları gibi konularda daha somut neler yapilabileceklerine dair sorular sorarak çocukları ile yaşadıkları çatışmaları en kısa yoldan çözmek istediklerini belirtmişlerdir. Bu durum ADDT'ye dayalı Eğitim Programı'nın anne babaların problem odaklı beklentilerine yanıt vermede yetersiz kaldığı söylenebilir. ADDT'ye dayalı Aile Eğitim programı daha çok anne babaların akılcı olmayan inançların fark etmeleri ve bu inançların daha işlevsel inançlarla değiştirilmesi üzerine odaklanmıştır. 7 haftalık programda sadece 1 hafta 
anne babaların başta çocukları olmak üzere diğer kişilerle daha sağlıklı ilişkiler kurmalarına yönelik iletişim becerileri eğitimi verilmiştir.

\section{Ebeveynlik Davranışlarna İlişkin Bulguların Sonuç ve Tartışması}

Bu çalışma ADDT’ye dayalı Aile Eğitim Programının annelerin ebeveynlik davranışları üzerindeki etkisini incelemektir. Araştırma kapsamında annelere uygulanan aile eğitim programının odak noktası annelerin akılcı olmayan inançlarından kaynaklanan ebeveyn rollerine ilişkin gösterdikleri tutum ve davranışları daha esnek ve akılcı inançlara dönüştürmektir. Böylelikle annelerin ebeveyn rollerinde gösterdikleri ve olumsuz ebeveyn davranışları olarak nitelendirilebilecek çocuğa yönelik şiddet, tutarsız disiplin uygulamaları, çocuk yetiştirirken gösterilen yetersiz destek gibi istenmeyen ebeveyn davranışlarının azaltılması çocukla ilgilenme ve olumlu ebeveynlik davranışlarının artması amaçlanmaktadır.

ADDT'ye dayalı Aile Eğitime Programı'nın annelerin çocuk yetiştirmeye ilişkin tutum, davranış ve uygulamaları üzerindeki kısa süreli etkilerini ortaya koymaktır. Elde edilen sonuçlar, aile eğitimine katılan annelerin akılcı olmayan inançlarından kaynaklanan çocukla ilgilenme ve olumlu ebeveynlik davranışlarının arttığı, yetersiz gözetim, tutarsız disiplin ve dayakla cezalandırma davranışlarının azaldı̆̆ı görülmektedir.

Uygulama sonunda eğitim programına katılan annelerin işlem öncesine göre çocuklarında algıladıkları davranış problemlerin azaldığı, kendi ebeveynlik rollerine ilişkin olumlu tutum ve davranışların arttığı olumsuz tutum ve davranışların azaldığı görülmektedir.

Çekiç tarafından geliştirilen ADDT'ye dayalı Aile Eğitim Programı'nın akılcı olmayan inançların azaltılmasında etkili olmasının nedeni programın ağırlıklı düşüncelerin belirlenmesi ve değiştirilmesi üzerine temellendirilmesinden ve bu konulara ilişkin oturum sayılarının fazla olmasından kaynaklandığı düşünülebilir(Çekiç, 2015).

ADDT'ye dayalı Aile Eğitim Programı'nın annelerin akılcı olmayan inançlarının azaltılmasında etkili olması, anneler ile çocukların ilişkilerine de olumlu katkı sağlayabilir.

\section{Araştırmanın Sintrlilikları}

Çalışmaya sadece anneler katılmıştır. Aile sistemi içerisinde yaşayan çocukların ve annelerin davranışları incelemek ve değiştirmek siteme bir bütün 
olarak müdahale etmeyi gerektirmektedir. Bu çalışmaya sadece annelerin katılması işlemin etkiliğini belirleyen önemli bir sinırlılıktır.

Anne-babalara yönelik hazırlanan Akılcı Duygusal Eğitim programı Gaziantep ili merkez ilçesi olan Şehitkâmil sınırlarında ilkokulda çocuğu olan anneler üzerinde geliştirilmiştir. Bu nedenle elde edilen bulgular ancak benzer özellikler gösteren annelerle sinırlıdır.

Araştırma kapsamında elde edilen veriler, Alabama Ebeveyn Davranışları Ölçeği ve Conners' Ana--baba Derecelendirme Ölçeğinin ölçebildiği nitelikler ile sinurlıdır.

Araştırmaya ilkokul 2. 3. ve 4. Sınıfta çocuğu olan anneler katılmıştır. Okula yeni başlayan çocuklar için okul sistemi çok yabancıdır ve bazı uyum sorunları yaşabilmektedirler. Dolayısıyla annelerin yaşadıkları güncel kaygılardan kaynaklı ölçek maddelerine sağlıklı cevap vermeme ihtimalleri dolayısıyla araştırmaya dâhil edilmemiştir.

$\mathrm{Bu}$ çalışmada öntest ve sontest uygulanmıştır. Zamansal gelişimi, uygulamanı uzun süreli etkililiği ya da değişimini takip edebilmek için izleme testi yapilamamıştır.

Arşatırma kapsamında uygulanan Psikoeğitim programında öğrenilenlerin davranışa dönüştürülmesi ve diğer aile üyelerinin de sürece katılmaları için ev ödevleri verilmiştir. Anneler zaman zaman ev ödevleri aksakmış, verilen şekilde yapmamışlardır. Bu Psikoeğitim programın programın tam olarak uygulanmasını engellemiştir.

\section{Öneriler}

$\mathrm{Bu}$ araştırmada ulaşılan sonuçlar çerçevesinde anne babalara yönelik düzenlenecek eğitim çalı̧̧malarına ve yapılacak araştırmalara yönelik öneriler aşağıda belirtilmiştir.

\section{Uygulayıcılar için öneriler}

1. İlkokulda çocukları olan anne ve babalara yönelik olarak geliştirilen ADDT' ye dayalı Aile Eğitim Programı kullanılmıştır. Program geliştirilip diğer yaş grubu ve farklı sosyo-ekonomik düzeydeki çocukların anne babalarına yönelik olarak yeniden düzenlenip uygulanabilir.

2. Annelere verilecek eğitim sadece Milli Eğitim Bakanlığı'na bağlı ilk ve ortaöğretim okullarında değil, Aile ve Sosyal Politikalar Bakanlığı, Be- 
lediyeler gibi bazı kurumlar tarafından desteklenebilir anne-çocuk sağlığı merkezlerinde, külüplerde, halk eğitim merkezlerinde, aile yaşam merkezlerinde, sosyal tesislerde vb. yerlerde de verilebilir.

3. Ailelere ihtiyaç analizi yapılarak anne babaların en çok ihtiyaç duydukları konuları içeren eğitim programı hazırlanıp uygulanabilir.

4. ADDT'ye dayalı Aile Eğitim Programı'nın etkililiğini arttırmabilmek için anne ve babaların çift olarak programa katılmaları sağlanabilir. Böylece eğitim programına katılacak olan ebeveynler, eğitim boyunca öğrendiklerini uygulamada yalnız kalmayacak ve diğer ebeveynin ihtimal direnci ile karşılaşmayabilir.

5. Anne ve babalar okullarda gerçekleştirilen eğitimlere sıklıkla devamsızlık yaptıkları bilinmektedir. Ayrıca okullarda görev yapan psikolojik danışmanların sayısı yetersiz, iş yükleri fazladır. Üniversite, özel resmi kuruluşlar ve medya ile işbirliği yapılarak anne baba çocuk eğitimine yönelik TV ve internet üzerinden online eğitim modelleri hazırlanabilir. Daha çok anne babaya ulaşmasını sağlayabilir ve okullarda çalışan psikolojik danışmanların da iş yükleri de hafifleyebilir.

6. İlkokula devam edip psikosomatik belirtiler gösteren öğrenci ve velilerine yönelik olarak daha spesifik eğitim programları hazırlanıp uygulanabilir.

\section{Araştırmacılar için öneriler}

1. 7-18 yaş çocuklarının akılcı olmayan inançlarından kaynaklana davranış problemleri incelenebilir. Grup rehberliği çerçevesinde ADDT'ye dayalı öğrenci eğitim programı geliştirilebilir.

2. ADDT'ye dayalı Aile Eğitim Programı'nın etkililiği diğer yaklaşımlara dayalı olarak geliştirilecek aile eğitim programları ile karşılaştıılabilir.

3. ADDT'ye dayalı geliştirilmiş olan Aile Eğitim Programı'nın etkililiği akılcı olmayan inançları yüksek olan ve bu konuda bir ruh sağlığı uzmanına başvuran anne ve babalar üzerinde sınanabilir.

4. Araştırma süresinde araştırmacının gözlemleri de araştırmaya katılan annelerin uygulanan eğitimden memnun oldukları, haftada bir de olsa evden uzaklaşmanın ve diğer anneler ile bir arada olmanın kendilerine iyi geldiğini belirttikleri görülmektedir. Ayrıca eğitime katılmak anneler tarafından kendilerine zaman ayırdıklarını bu da anne babaların kendilerini daha özgür ve daha az kısıtlanmış hissetmelerine yol açtı̆̆ı söylenebilir. 


\title{
EXTENDED ABSTRACT
}

\section{The Effect Of Family Education Programme On Mothers' Parenting Behaviors And Behaviour Problems Of Their Children}

\author{
Ali Çekiç - Çiğdem Altuntaş \\ Gaziantep University
}

Urbanization process began with the industrial revolution, the participation of women in the labor force and shrinking family structures with urban life and the world as well as in institutions in Turkey has led to families in time of serious change. These changes in the structure of the family have brought some problems. It has made it difficult for parents to access informal channels where they can get support for family and child education (Hareven, 1982; cited in: Staton et al. 1991). Therefore, traditional support channels are changing, and families may need education programs that will support them and contribute to raising children (Kılıç, 2010).

Children and teenagers may show problematic behaviors during the development process. Problem behaviors are characterized by the personality of the child when appropriate precautions are not taken, and can lead to behaviors that require legal punishment in adulthood, academic inadequacy, problem of adaptation to the social environment, and the growth and continuity of the problem (Rocha-Decker, 2004).

In studies conducted with children who were thought to have behavioral problems, it was observed that the mothers of children who showed the problem had poor communication skills and displayed unhealthy parental attitude when approaching their children. It is thought that the quality of the bond between mother and child is effective in children to acquire social skills, to enable them to control themselves, to internalize the child while acquiring a role model (Turan, 2004).

The irrational beliefs of mothers about both themselves, the people they have relationships with and their parenting roles can have some negative consequences. While mothers with poor rational thinking skills may have negative feelings and behaviors about themselves, parenting beliefs and behaviors shaped by these beliefs may also contain negative features. More- 
over, the early stages of development include many critical periods for children, and negative parental behaviors encountered during these periods may also affect adolescence and adulthood.

At the end of family education programs, it is seen that parents feel themselves more knowledgeable, equipped and competent about child education and development, and they can intervene and produce permanent solutions to their children's behavioral problems. It has been observed that the parent model contributes to their children's academic success that supports their children's personality development in social and psychological aspects positively (Temel, 2010).

The aim of this research is to examine the effect of the Family Education Program based on REBT on the parenting behavior of mothers. In addition, within the scope of the research, the effect of the family education program on the behavioral problems perceived by mothers in their children will be examined.

Alabama Parental Behavior Scale and Conners' Parent Rating Scale (CPRS) were applied to 351 mothers whose children were attending public primary school in Gaziantep to determine the mothers to be included in the study. Informing the experimental and control groups, only the total scores of CPRS were taken into account. At the end of the applied scales, interviews were conducted with 55 mothers who scored one full standard deviation $(\mathrm{Sd}=13.79)$ above the arithmetic mean $(=72.70)$ of the scores obtained by the group $(\mathrm{n}=351)$. As a result of the interviews, 14 mothers who were willing to participate in the training program, who did not have any pathological problems or did not receive any psychological treatment, and who could participate in the training program on the common day and time were included in the experimental group. 14 mothers who scored one full standard deviation above the arithmetic mean of CAD but accepted to participate in the posttest measurements who were not included in the education were also included in the control group. Following the pretest measurements, the Rational Emotional Family Education Program, developed by Çekiç (2015), which consists of 7 sessions, was applied to the mothers in the experimental group, aimed at alleviating the irrational perfect-complete thoughts and expectations about parenting, and bringing healthier and more effective thoughts. Posttest measurements were carried out with the 
experimental group 1 week after the end of the applications. In the analysis of the obtained data, $2 \times 2$ way variance analysis technique was used.

In result of analysis, compared to mothers who did not attend the parent education program, decrease in behaviors perceived as problem by mothers who attended the program were exhibited. The education program applied in this study have mainly focused on non-rational beliefs. It can be interpreted that it is also effective on behavioral problems in children perceived by their mothers with minimizing non-rational thoughts. While it has been observed a decrease in children behaviors perceived as problem by mothers compared to before the process in sub-dimensions of ADHD and behavioral problems, in respect of sub-dimensions of learning problems, anxious behaviors and psychosomatic behaviors, it has not been observed a significant difference in mothers evaluation of their children's behaviors. both mothers who attended the program acquiring more rational reasoning skills with changing their thoughts and in result of learning the behaviors originated from children's normal developmental stage instead of perceiving as problem or naughtiness, and their realization of other mothers experiencing similar behaviors in their children are thought to be effective in this change.

According to the acquired findings revealed short term effects of parent education program based on REBT on mothers' attitude, behavior and practices toward raising children. According to the results, while it has been observed an increase in behaviors of positive parenting and caring children, a decrease in behaviors of insufficient observance, inconsistent discipline and chastise rooted from non-rational beliefs of mothers who attended the program.

As a result, it can be said that mothers who participated in the family education program have increased positive behaviors about parenting behaviors and evaluate their children's behaviors more positively. Fathers were not included in the study, both during the data collection phase and implementation of the training program. The exclusion of fathers, who have an important place in raising children, creates a limitation in terms of the effects of the education program on children. The mothers stated that there was no problem in the application in the family environment, where what was learned during the application was shared fully and effectively with the other parent and caused a positive change in their behavior as a parent, but the other parent should participate in the study in order to increase its effec- 
tiveness. In order to increase the effectiveness of the Family Education Program, parents can be encouraged to participate in the program as a couple. Thus, the parents who will participate in the training program will not be alone in applying what they have learned during the education and may not encounter the potential resistance of the other parent.

During the study period, the researcher's observations were also observed that the mothers who participated in the study were satisfied with the training applied and stated that it was good for them to stay away from home and be together with other mothers even once a week. In addition, it can be said that the mothers allocate time for themselves by participating in the education, which makes the parents feel freer and less restricted.

\section{Kaynakça / References}

Aksoy, A. B. (2005). Farklı kültürlerde ebeveynlik. Kastamonu Eğitim Dergisi, 13(2), 333338.

Alisinanoğlu, F., ve Kesicioğlu, O., (2010) Okul öncesi dönem çocuklarının davranış sorunlarının çeşitli değişsenler açısından incelenmesi. Gazi Eğitim Fakültesi, Kuramsal Eğitim bilim Dergisi, 3(1), 93-110.

Apter, S. J. (1982). Troubled children/troubled systems. Oxford: Pergamon Press Ltd.

Arl, R. (2005). Gelişim ve öğrenme. 2. Baskl, Ankara: Nobel Yayın Dağıtım.

Bağcl, C. (2013). Anne-babalarm aklcı olmayan inançlarmm aile işlevi ve çocuklardaki davranış problemleri arasındaki ilişkinin incelenmesi. Yüksek Lisans Tezi, Gaziantep Üniversitesi Eğitim Bilimleri Enstitüsü.

Baltaş, A. ve Baltaş, Z. (2002). Stres ve başaçıkma yolları. Remzi Kitabevi. İstanbul.

Beautrais, A. L., Fergusson, D. M. ve Shannon, F. T. (1982). Family life events and behavioral problems in preschoolaged children. Pediatrics, 70(5), 774-779.

Büyüköztürk, Ş., (2010). Deneysel desenler. Ankara: Pegem Akademi Yayıncllk

Can, A., (2014). Spss İle Bilimsel Araştırma Sürecinde Nicel Veri Analizi. Ankara: Pegem Akademi Yayınclık

Can, G.(2011).Gelişimin doğası. (Ed. E. Ceyhan). Erken Çocukluk Döneminde Gelişim I. içinde (s.1-24) .Eskişehir: Anadolu Üniversitesi Açı Öğretim Fakültesi Yayı$\mathrm{ni}$,

Çağan, K. (2011). Ailenin işlevleri, aile hakknda kuramsal perspektifler. Ed. K.Canatan, Aile Sosyolojisi, içinde (s.84) İstanbul:Açlım Kitap.

Çağdaş, A. (2009). Anne-baba-çocuk iletişimi. Ankara: Kök.

Çağdaş, A. (2012). Anne-baba-çocuk iletişimi. Ankara: Eğiten. 
Çekiç, A. (2015). Akılcı duygusal aile eğitim programmm anne babalarn akılı olmayan inançlar ve anne babalk stresleri üzerine etkisi. Doktora Tezi, Çukurova Üniversitesi Sosyal Bilimler Enstitüsü.

Çekiç, A. Türk, F. Buğa, A. ve Hamamcı, Z. (2018). Alabama ebeveyn davranışları ölçeği'nin türkçe 'ye uyarlanması geçerlik ve güvenirlik çalışması. Elektronik Sosyal Bilimler Dergisi, 17(66), 728-743.

David, O., Joyce, M. ve David, D., (2011). Cognitive behavioral parent programs for the treatment of child disruptive behavior. Journal Of Cognitive Psychotherapy 25(4), 240-256 Dor: 10.1891/0889-8391.25.4.240

Demirkaynak, Ö., Aktaş, N., ve Hasipek, S. (2006). 3-6 yaş grubunda çocuğu olan annelerin beslenme bilgi düzeyleri ve beslenme alıskanlıkları. Avrupa Birliği Sürecinde Okul Öncesi Eğitimin Geleceği Sempozyumu, İstanbul.

Dereboy, Ç., Senol, S., Sener, Ş. ve Dereboy, F. (2006). “Conners' kisa form ögretmen ve anababa derecelendirme ölçeklerinin geçerligi." Türk Psikiyatri Dergisi. 17 (2).

Dereboy, Ç. Şenol, S. Şener, Ş. Dereboy, F. (2007). Conners' Kısa form öğretmen ve ana baba derecelendirme ölçeklerinin geçerliği, Türk Psikiyatri Dergisi; 18(1), $48-58$

Dizman, H. (2003). Anne babast ile yaşayan ve anne yoksunu olan çocuklarm saldirganlik eğilimlerinin incelenmesi. Yayınlanmamış Yüksek Lisans Tezi, Ankara Üniversitesi Fen Bilimleri Enstitüsü.

Ellis, A., Moseley, S. ve Wolfe, J. L. (1966). How to raise an emotionally healhy child. melvin powers willshire book company. Hollywood.

Engin, E. C. (2015). Bir aile hekimliği bölgesinde kayttl 6-18 yaş arası çocuk ve ergenlerde görülen davranış ve uyum problemlerinin; bu çocuk ve ergenlerin ailelerinin demografik özellikleri, tutum ve davranışlarıyla olan ilişkisinin incelenmesi. Yayınlanmamış Yüksek Lisans Tezi, Üsküdar Üniversitesi, İstanbul.

Erikson, E.H. (1968). Identity: Youth And Crisis, New York: W.W. Norton ve Company,Inc.

Gavita, O. A., Joyce, M. R. ve David, D. (2011). Cognitive Behavioral Parent Programs For The Treatment Of Child Disruptive Behavior. Journal Of Cognitive Psychotherapy: An International Quarterly. 25(4). 240-257.

Geçtan, E. (2008). Psikanaliz ve sonrası (13. Basım). Ankara: Hür Yayınları.

Geçtan, E. (2013). Psikodinamik psikiyatri ve normaldışı davranışlar, (21. Baskı).İstanbul: Metis Yayıncilik.

Giannaris Wj, Golden Cj, Greene I ve Ark. (2001) The Conners' parent rating scales: a critical review of the literature. Clin Psychol Rev, 21, 1061-1093. 
Gökmen, C. O. (2004). İlköğretim 1. kademede müzelerin öğretim ortamı olarak yeri. Tezsiz Yüksek Lisans Projesi, Ankara Üniversitesi Sosyal Bilimler Enstitüsü Müze Eğitimi Tezsiz Yüksek Lisans Programi; 21-22.

Grusec, J.E., ve Davidov, M. (2007). Socialization in the family: The roles of parents. In J.E. Grusec and P.D. Hastings (Ed.), Handbook of socialization: Theory and research (p.284-309). New York: The Guilford Press.

Hamamc1, Z. (2007). Anne babalara yönelik eğitim programlarının geliştirilmesi ve uygulanması. (Ed.) Y. Kuzgun ve Z. Hamama. Anne baba eğitim programlarn İçinde, (1-26). Maya Akademi, Ankara.

Hauck, P. A. (1967). Rational management of children. Libra Publisher. New York, p.22.

Joyce, M. (1995). Emotional reliefs for parents: is rational emotive parent education effective? Journal Of Rational- Emotive ve Behavior Therapy, 13, 55-75.

Kağıtçıbaşı, Ç. 2006). Theoretical perpectives on family change. Families Across Cultures. (Ed.) Georgas, J. Et. All A 30-Nation Psychological Study'nin içinde Cambridge University Press. Cambridge.

Kandır, A. (2000). Öğretmenlerin beş-altı yaş çocuklarında görülen davranış problemlerine ilişkin bilgi ve tutumları. Gazi Üniv. Mesleki Ĕ̆itim Fakültesi Dergisi, 2(1), 42-50.

Kaya, Ö. M. 2002. Okul öncesi eğitim kurumlarnda uygulanan programlara ailelerin ilgi ve katılımlarn ile okul öncesi eŏitim kurumlarmın aile eğitimine katkısı konusunda annebaba görüşleri. Yüksek Lisans Tezi (Yayınlanmamış), Anadolu Üniversitesi, Eğitim Bilimleri Enstitüsü, Okul Öncesi Öğretmenliği, Eskişehir

Kılıç, Ç. (2010). Aile eğitim programları ve Türkiye'deki örnekleri. Abant İzzet Baysal Üniversitesi Dergisi, 10(1), 99-111.

Krol N., Morton J., De-Bruyn E. (2004) Theories of conduct disorder: A causal modelling analysis. J Child Psychol Psychiatry; 45, 727-742.

Kulaksızoğlu, A. (2008). Ergenlik psikolojisi (10. Bask1). İstanbul: Remzi.

Özdemir, O., Özdemir, P. G., Kadak, M. T. ve Nasıroğlu, S., (2012). Kişilik gelişimi, psikiyatride güncel yaklaşımlar, 4(4), 566-589.

Pais, S. (2006). Globalization and it's impact on families. 4. Vienesse Conference On Mediation. Vienna, Austria.

Rocha-Derker, M.S.(2004).The development and validation of the proactive assesment of social skill for preschool children. Unpublished Doctoral Dissertation. Presented To The College Of Education And The School Of Universty Of Oregon. Proquest Information And Learning Company.

Poole, M. (2005). Family: Changing families, changing times. Allen ve Unwin Press. Australia. 
Shelton, K. K.,Frick, P. J., ve Wootton, J. (1996). Assessment of parenting practices in families of elementary school-age children. Journal Of Clinical Child Psycho$\log y, 25,317-329$. Doi:10.1207/S15374424jccp2503_8

Starko, T. J. (1991). Parent stress and parent trrational beliefs: mother-father differences. Yüksek Lisans Tezi. Department Of Educational Psychology. University Of Alberta. Edmontan, Alberta.

Staton, J. ,Ooms, T.Owen, T.(1991). Family Resource,support and parent education programs:The power of a preventive approach. Politic Institu For Family Impact Seminars, Washington,Dc. 1-19.

Stimac, T. M. (1985). The impact of a cognitively-oriented parent education program on parents' rationality of beliefs and the family environment. Doktora Tezi. Division Of Counselling And Educational Psychology. University Of Oregon.

TDK, (2018). Sözlük. 28.12.2018 Tarihinde Http://Www.Tdk.Gov.Tr/Index.Php?Option=Com Btsve View=Btsve Kategori1=Veritbnve Kelimesec=6973 Erişildi.

Temel, F.(2010). Aile eğitimi ve erken çocukluk eğitiminde aile katılım çalışmaları. Ankara: Ant.

Tezel Şahin, F. ve Cevher Kalburan, F. N. (2009). Aile eğitim programları ve etkililiği: dünyada neler uygulanıyor? Pamukkale Üniversitesi Eğitim Fakültesi Dergisi, 1(25), 1-12.

Tezel Şahin, F., Özbey, S.(2007). Aile eğitim programlarına niçin gereksinim duyulmuştur? aile eğitim programları neden önemlidir?, Aile ve Toplum Kültür ve Araştırma Dergisi, 3 (12), 7-12.

Turan, Z. (2004). Ailede ruh sağlığı. Y. Uzuner (Ed.), Çocukta Ruh Sağhı̆̆ı, Uyum Bozukluğu. Eskişehir: Anadolu Üniversitesi Yayınları

Yavuzer, H. (1996). Çocuk ve suç (8.Bask1). İstanbul: Remzi Kitapevi.

Yavuzer, H. (2013). Ana-baba ve çocuk, (24. Baskı). İstanbul: Remzi Kitabevi.

Tavşancıl, E. (2010). Tutumlarm ölçülmesi ve SPSS ile veri analizi. Ankara: Nobel Yayın Dağıtım.

Tezbaşaran, A. A. (1997). Likert tipi ölçek geliştirme kılavuzu. Ankara: Türk Psikologlar Derneği.

Trompenaars, F. ve Voerman, E. (2009). Servant-leadership across cultures: Harnessing the strengths of the world's most powerful management philosophy. New York: The McGraw-Hill Companies.

Vinod, S. ve Sudhakar, B. (2011). Servant leadership: A unique art of leadership, Interdisciplinary Journal of Contemporary Research in Business, 2(11), 456-467. 
Yılmaz, V. ve Çelik, H. E. (2009). Lisrel ile yapısal eşitlik modellemesi I temel kavramlar, uygulamalar, programlama. Ankara: Pegem Akademi Yayınalık.

\section{Kaynakça Bilgisi / Citation Information}

Çekiç, A. ve Altuntaş, Ç. (2020). Aile eğitim programının annelerin ebeveynlik davranışlarına ve çocuklarında gözlenen davranış problemlerine etkisi. OPUS-Uluslararası Toplum Araştırmaları Dergisi, 16(31), 3867-3898. DOI: 10.26466/opus.704706 